\section{A rota cultural na senda da paisagem, da cultura, do património, das tradições, das lendas: o exemplo do Alto Barroso (Norte de Portugal)}

Resumo: Rotas, percursos ou trilhos constituem valiosos guias que orientam a descoberta de um território desconhecido. A exploração de um espaço geográfico e a compreensão da sua identidade é um processo que implica uma relação longa e exigente entre o observador e o território. Este processo de conhecimento requer disponibilidade para permanecer, percorrer, ver, cheirar, sentir, interpretar, relacionar elementos, apreender padrões, identificar contrastes. Devido à morosidade e exigência deste processo, a riqueza e diversidade de uma paisagem permanecem frequentemente ocultas face ao olhar do turista. É precisamente este o papel desempenhado por uma rota turística, conduzir e motivar o olhar interpretativo sem, no entanto, condicionar a liberdade de opção e o interesse pessoal do turista. Nesse sentido, uma rota turística não deve restringir-se ao traçar de um dado trajeto, tendo por missão dar visibilidade a todas as dimensões da paisagem e contribuir para a compreensão da interação de fatores que se encontra na sua génese. A concepção de uma rota original, tendo tema âncora a Paisagem cultural do Alto Barroso, Norte de Portugal, tem como objetivo demonstrar o nosso conceito de rota turística, salientando a sua inegável importância enquanto instrumento de apoio à exploração de um território sob o ponto de vista do turismo interpretativo, cultural e sensorial. É neste sentido que defendemos uma perspectiva inovadora dos territórios enquanto produto turístico e uma visão do turismo como eixo de mobilização de atores e dinâmicas de desenvolvimento. A rota aqui proposta pretende abarcar a interpretação da paisagem, algumas vivências culturais dos povos do Alto Barroso e, ainda, sentir a essência dos territórios que constituem esta região. Tem como base um percurso para veículos motorizados, mas houve a preocupação de fazê-la passar por locais que permitissem a ligação com percursos pedestres ou, pequenas rotas assinadas na região e, para os quais já existe sinalização e informação disponibilizada por organismos locais, nomeadamente pelas Câmaras Municipais e Ecomuseu do Barroso.

\section{The cultural route in the path of the landscape, culture, heritage, traditions, legends: the example of the Alto Barroso (North of Portugal)}

\footnotetext{
Abstract: Routes, paths or trails are valuable guides to discovery of an unknown territory. The exploitation of a geographical space and understanding of their identity is a process that involves a long and demanding relationship between the observer and the territory. This process requires the availability of knowledge to stay, go, see, smell, feel, interpret, relate elements, grasp patterns, identify contrasts. Due to the lengthy and demanding this process, the richness and diversity of a landscape often remain hidden face to the tourist gaze. This is precisely the role of a tourist route, lead and motivate the interpretive look without, however, restrict the freedom of choice and self-interest of the tourist. In this context, a tourist route should not be restricted to the trace of a given path, with the mission to give visibility to all aspects of the landscape and contribute to understanding the interaction of factors that is in its genesis. The design of an original route, having theme anchor the cultural landscape of the Alto Barroso, Northern Portugal, aims to demonstrate the concept of our tourist route, emphasizing its undeniable importance as a tool to support the exploration of a region from the point of view of interpretation, cultural and sensory tourism. This is why we advocate a new perspective of the territories as a tourism product and a vision of tourism as an axis of mobilization of actors and dynamics of development. The route proposed here is intended to encompass the interpretation of the landscape, some cultural experiences of peoples of the Alto Barroso, and feel the essence of the territories that constitute this region. It is based on a route for motorized vehicles, but there were concerns make it pass by places that allow the connection footpaths or small signed routes in the region, for which there is already signaling and information provided by local agencies, including by local councils and the Ecomuseum Barroso.
}

António de Sousa

Pedrosa*

\begin{abstract}
* Professor Associado da Faculdade de Letras da Universidade do Porto, Professor Visitante do Programa de Pós-graduação da Universidade Federal de Uberlândia - UFU (Bolsista CAPES), membro do Centro de Estudos de Geografia e Ordenamento do Território (CEGOT).
\end{abstract}

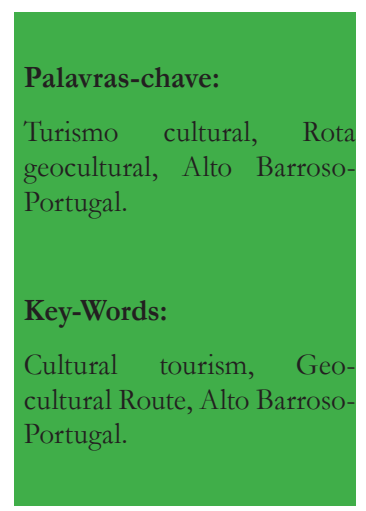


"Ser barrosão é uma condição própria, não é uma pátria, mas é uma honra".

Prof. José Hermano Saraiva

\section{Introdução}

Rotas, percursos ou trilhos constituem valiosos guias que orientam a descoberta de um território desconhecido. A exploração de um espaço geográfico e a compreensão da sua identidade é um processo que implica uma relação longa e exigente entre o observador e o território. Este processo de conhecimento requer disponibilidade para permanecer, percorrer, ver, cheirar, sentir, interpretar, relacionar elementos, apreender padrões, identificar contrastes. Devido à morosidade e exigência deste processo, a riqueza e diversidade de uma paisagem permanecem frequentemente ocultas face ao olhar do turista. É precisamente este o papel desempenhado por uma rota turística, conduzir e motivar o olhar interpretativo sem, no entanto, condicionar a liberdade de opção e o interesse pessoal do turista. Nesse sentido, uma rota turística não deve restringir-se em traçar um dado trajeto, tendo por missão dar visibilidade a todas as dimensões da paisagem e contribuir para a compreensão da interação de fatores que se encontra na sua génese (PEDROSA, PEREIRA 2008, 2012).

A concepção de uma rota original, tendo tema âncora a Paisagem cultural do Alto Barroso, Norte de Portugal, tem como objetivo demonstrar o nosso conceito de rota turística, salientando a sua inegável importância enquanto instrumento de apoio à exploração de um território sob o ponto de vista do turismo interpretativo, cultural e sensorial (Figura 1).

Como turismo interpretativo, designamos um processo ativo e participado de análise e compreensão do território e da paisagem nas suas múltiplas dimensões: ambiental, biogeofísica, histórica e produtiva. A definição de percursos de observação é, nesta modalidade turística, fundamental para o estímulo e orientação do olhar interpretativo, fomentando o contato com realidades em interação que no seu conjunto moldam a identidade dos lugares e das regiões (ALCANTARA, 2007).

O turismo cultural, complementar do primeiro, promove a experiência concreta de ambientes culturais específicos de determinadas regiões ou comunidades, através da aproximação aos seus valores, tradições e estilos de vida, do conhecimento do seu património e das suas artes visuais e decorativas ou até mesmo da participação lúdica nas suas atividades quotidianas da esfera produtiva, lúdica e religiosa (PEREIRA, PEDROSA, 2007, 2010; PÉREZ, 2009).

Por último, o turismo sensorial, situando-se na esfera da vivência pessoal do processo através dos sites: <http:// www.rotas.xl.pt/0203/a0200-00.shtml>; <http://www. cm-montalegre.pt/>; <http:// www.ecomuseu.org/ $>$; $<$ http://www.cm-boticas.pt/>.

Geografia Ensino \& Pesquisa, v. 17, n.3, p. 191-208, set./dez. 2013

A rota cultural na senda da paisagem, da cultura, do património, das tradições.... de descoberta de um novo espaço, apreende o território através dos sentidos, propondo percursos de exploração de territórios musicais, de novos olhares sobre paisagens evolutivas ou de rotas de sabores gastronómicos regionais (PEDROSA, PEREIRA, 2012).

É neste sentido que defendemos uma perspectiva inovadora dos territórios enquanto produto turístico e uma visão do turismo como eixo de mobilização de atores e dinâmicas de desenvolvimento.

A rota aqui proposta pretende abarcar, para além da interpretação da paisagem, algumas vivências culturais do povo do Alto Barroso e, ainda, sentir a essência dos territórios que constituem esta região. Tem como base um percurso para veículos motorizados, mas houve a preocupação de fazê-la passar por locais que permitissem a ligação com percursos pedestres ou, pequenas rotas assinadas na região e, para as quais já existe sinalização e/ou informação disponibilizada por organismos locais, nomeadamente pelas Câmaras Municipais e Ecomuseu do Barroso'. 


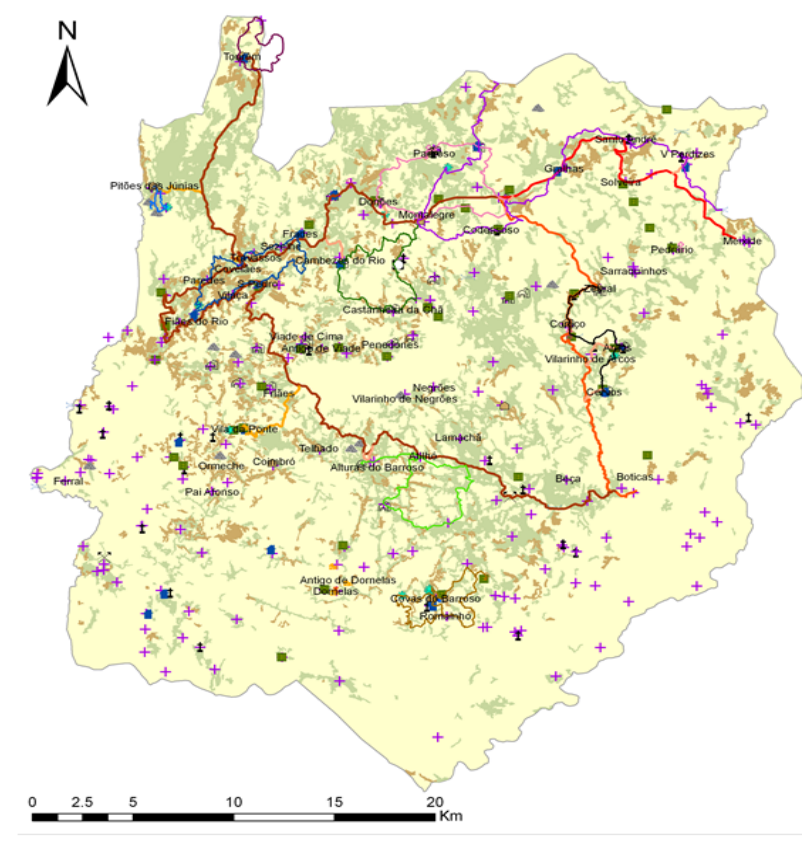

Rota Cultural e Paisagística

\begin{tabular}{|c|c|c|}
\hline Rota & do Alto Barroso & Património \\
\hline & Rota principal & - Vestigios arqueológicos \\
\hline & Saída por Boticas & Ponte \\
\hline & Saída por Chaves & + Igreja/Capela \\
\hline & Conexão a aldeias históricas & aii Forno Comunitário \\
\hline & Conexão a aldeias típicas & $\approx$ Espiguero \\
\hline & Rota do Contrabando & I Cruzeiro \\
\hline & Percurso das Alturas do Barroso & - Solares \\
\hline & Rota de Santiago & $\times$ Minas \\
\hline & Percurso de Covas do Barroso & - Fontes antigas \\
\hline & Trilho de Pitões das Júnias & $\begin{array}{ll}x & \text { Pelourinho }\end{array}$ \\
\hline & Trilho do Leiranço & Alminhas \\
\hline & Trilho do Ourigo & Arquitectura Vernacula \\
\hline & Trilho do Rio & Sítios Geomorfológicos \\
\hline & Trilho da Serra da Vila & - Moinhos \\
\hline & Povoações principais & a Fojo do Lobo \\
\hline & Mata de Carvalhos & \\
\hline & Pastagens naturaise sem & \\
\hline
\end{tabular}

Fonte: Organizado pelo autor com base em: Cartas militares do exército 1/25000; Ecomuseu do Barroso; IGEO.

\section{Na senda das "Alturas", terras de pão e de águas de lima}

Propomos que a rota se inicie na sede do concelho de Boticas, tomando a direção do planalto do Barroso, onde se desenvolvem as áreas de lameiros mais extensas desta região, que se relacionam com a existência de vastas áreas planas de altitudes elevadas e, de um tipo de granito, que permitiu o desenvolvimento de um manto de alteração profundo, tendo possibilitado o aparecimento de solos profundos e, disponibilidade hídrica suficiente para a prática da irrigação. Os lameiros associados à rega de limaª são uma constante ao longo do percurso (Figura 2). Estes correspondem a prados permanentes ou seminaturais, irrigados ao longo de todo o ano, apresentando-se como um dos sustentáculos da identidade paisagística do Alto Barroso (PIRES et al., 1994; PEDROSA, PEREIRA, 2009ª 2012, 2013). Eles traduzem diversas funções, nomeadamente as ambientais já que possuem um papel ecológico relevante na conservação da biodiversidade animal e vegetal (POÇAS, CUNHA, PEREIRA, 2006), mas mantém, também, as tradicionais funções econômicas já que são a base da alimentação do efetivo pecuário autóctone, a raça bovina barrosã, que no passado servia como força de trabalho assumindo, na atualidade, características de produção da carne certificada do Barroso.

Propõe-se uma paragem nas proximidades das povoações de Alturas do Barroso e Atilhó, onde se pode apreciar a arquitetura vernacular das aldeias em si, assim como, exemplares importantes de arquitetura religiosa. Os fornos do povo existentes nestas aldeias são peças de arquitetura popular típica, ao mesmo tempo que correspondem a um símbolo da cooperação comunitária, imposta pelas necessidades do pão de cada dia (Figura 3). Todos construídos em granito, até a cobertura é de lages ou cápias 3 . Interiormente arcos românicos seguram a abóbada da fornalha e o capeado. Quando eram utilizados para cozer do pão de centeio ${ }^{4}$, cada "vizinho" era obrigado a "quentar" o forno na sua vez e quem aquecia o forno é que determinava a ordem de cada vizinho para cozer o seu pão.
${ }^{2}$ A "rega de lima" corresponde a um sistema de rega por gravidade tradicional. Esta rega cumpre o objectivo da regulação térmica do solo e da vegetação, favorecendo o balanço energético da pastagem: "Através de um engenhoso conjunto de regadeiras de ordem bierárquica sucessivamente menor, o caudal disponivel é dividido de forma a que toda a parcela a regar fica coberta por uma lâmina de água que é recolbida por outra regadeira a jusante e finalmente, a parte que não se infiltra, devolvida ao curso de água depois de limar toda a parcela". (PEREIRA, SOUSA, 2005).

${ }^{3}$ Em tempos mais recuados podiam ter a cobertura em colmo. Mas os incêndios frequentes que ocorriam, levaram á sua substituição por lages graníticas.

${ }^{4} \mathrm{O}$ processo de fazer o pão obedece a determinados procedimentos. Colocase água a aquecer com sal, enquanto se peneira a farinha para dentro de uma masseira. A essa farinha junta-se a água, o fermento e amassase tudo muito bem. Uma vez feita a massa, coloca-se numa pilha dentro dum cesto para levedar, com a mão faz-se uma cruz na massa e costuma dizer-se uma pequena oração, de que encontramos diversas variantes, para esta levedar.

Geografia Ensino \& Pesquisa, v. 17, n.3, p. 191-208, set./dez. 2013.

Pedrosa, A. S. 
Figura 2 - Os lameiros e a rega de lima no Alto Barroso.

\begin{abstract}
${ }^{5}$ De um modo geral, existe uma multiplicidade de fontes de água (água de superfície e água subterrânea) e infraestruturas de regadio dentro da área de cada aldeia. As características hidrológicas incluem uma grande variabilidade de fluxos de água durante o calendário agrícola e uma elevada interconexão das fontes de água. Os sistemas e as redes de regadio são compostos por várias fontes de água espalhadas pelo termo da aldeia, reservatórios, canais e campos, interligados de diversas formas, o que, à primeira vista, dá uma impressão caótica. Entrelaçado a esta complexa $\mathrm{e}$ interligada infra-estrutura de regadio encontra-se o acesso do agricultor à água de rega, sob diferentes formas de propriedade. A contribuição destes sistemas no que respeita à disponibilidade total de água ao nível da exploração agrícola,é específica para cada agricultor (DRIES, 2002).
\end{abstract}

Geografia Ensino \& Pesquisa, v. 17, n.3, p. 191-208, set./dez. 2013

A rota cultural na senda da paisagem, da cultura, do património, das tradições....

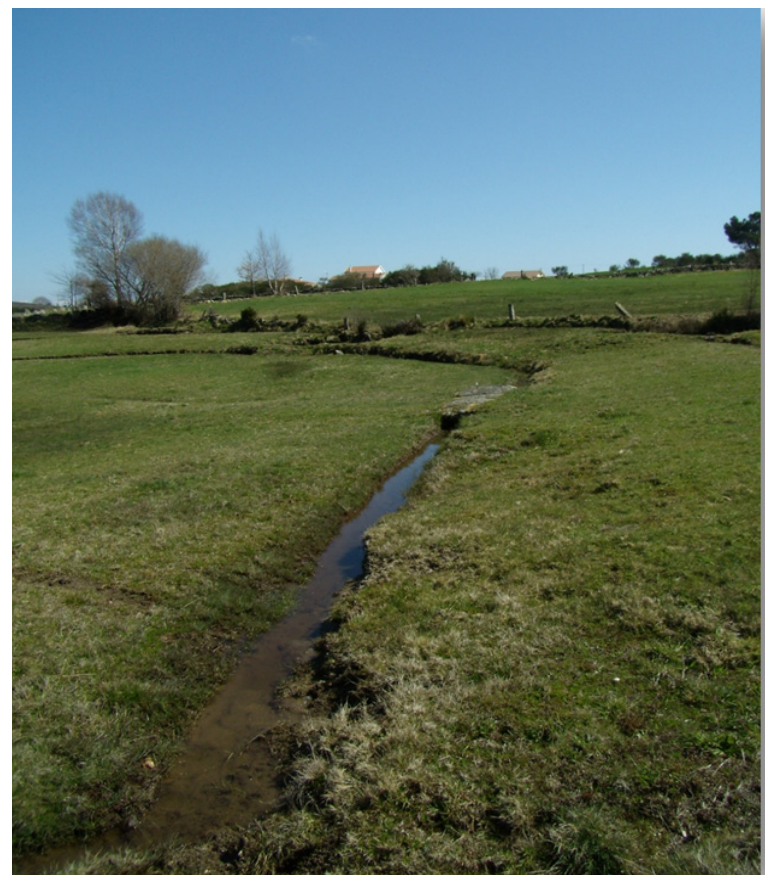

Fonte: PEDROSA, 2009.

Figura 3 - O forno comunitário do Alto Barroso.

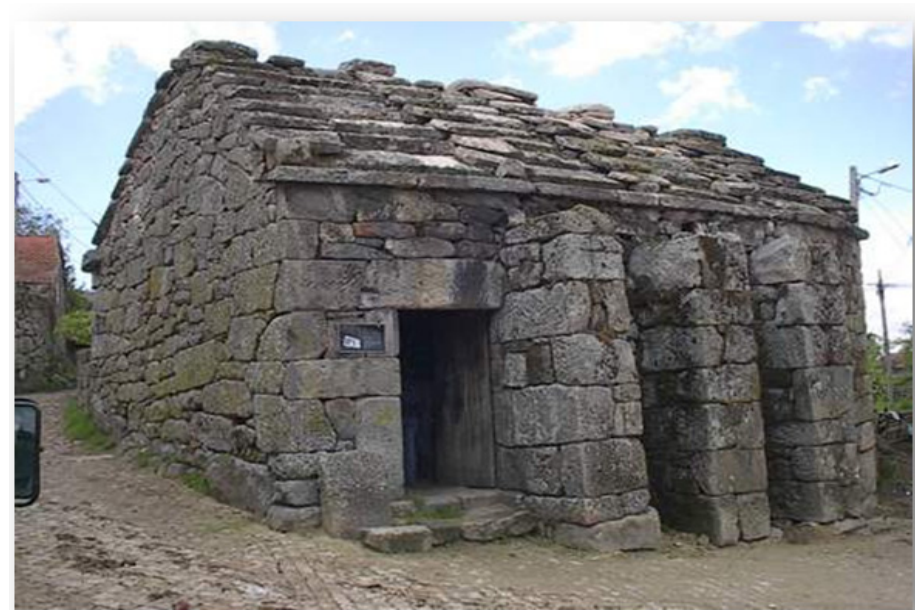

Fonte: BAPTISTA, 2006.

Neste ponto da rota pode iniciar-se o percurso - "Trilho das Alturas" (Figura 4) - que se desenvolve por caminhos rurais, que passam por entre os lameiros e pequenos carvalhais e, permitem apreciar as muitas espécies de flora e fauna, nomeadamente aves, que predominam nesta paisagem. Podem observar-se os tanques/poças de armazenamento de água de onde partem os canais de rega - regos - que permitem a tradicional "rega de lima". De forma evitar desperdícios da água de rega, o sistema de rotação da água é feito, geralmente, de acordo com o ordenamento dos terrenos. Este sistema de direitos continua a ser transmitidos de geração em geração através da tradição oral ${ }^{5}$. O trilho permite ainda visitar diversos moinhos de água, mais um elemento da cadeia do fabrico do pão, onde se pode apreciar o reconhecimento das estruturas de moagem tradicionais, e a identificação em pormenor dos elementos constituintes de cada moinho e do seu inter-relacionamento, em especial nos aspectos funcionais (C. M. de Boticas, s/d). 
Figura 4 - O trilho das Alturas e os seus principais elementos patrimoniais e paisagísticos.

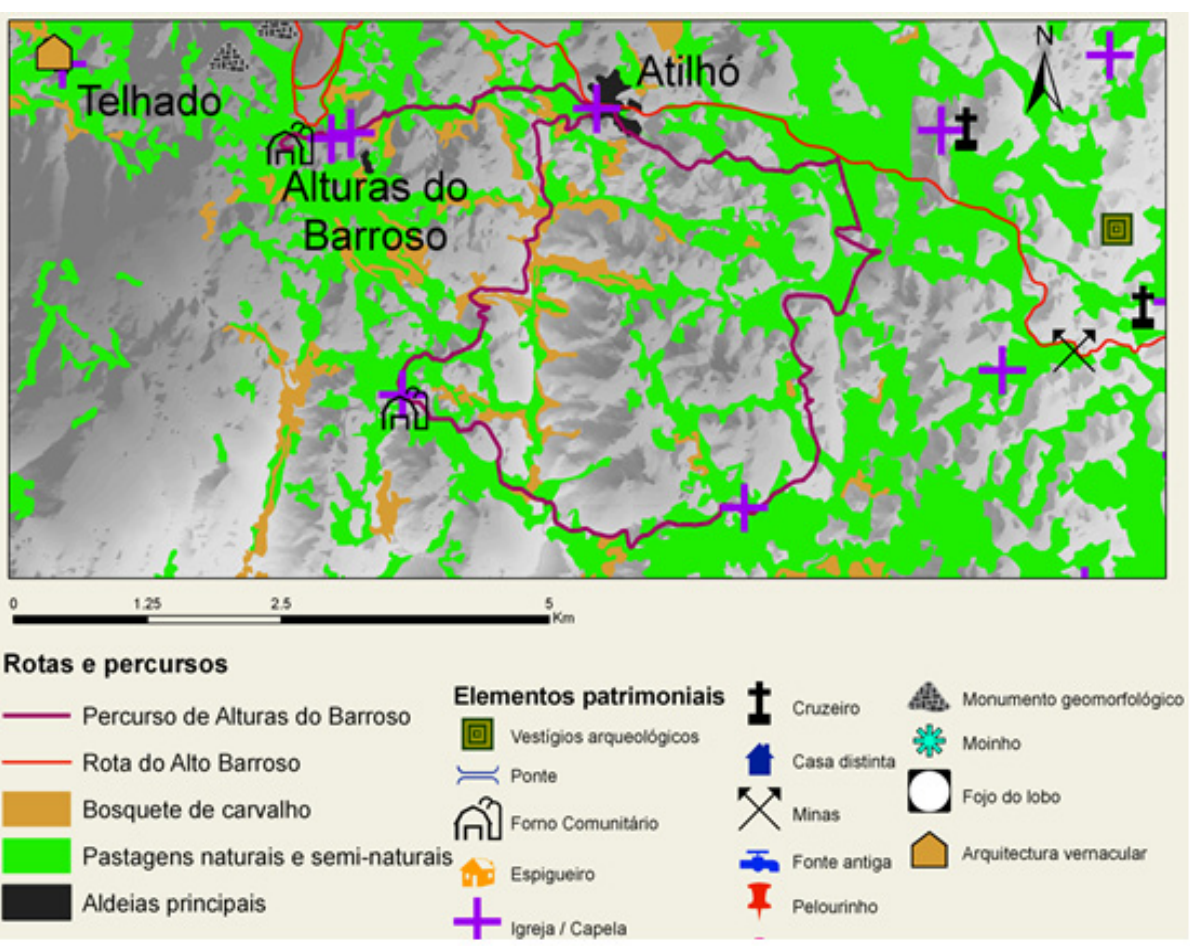

Fonte: Organizado pelo autor com base em: Cartas militares do exército 1/25000; Ecomuseu do Barroso; IGEO.

\section{Na procura das terras perdidas pelo rio empresado}

A rota continua em direção à barragem do Alto de Pisões, que permite atravessar o Rio Rabagão. O percurso passa por um geomonumento importante denominado localmente pelos "Cornos das Alturas do Barroso" onde os celtas estrategicamente desenvolveram uma povoação - o castro do Coto dos Corvos - de onde dominavam o planalto das Alturas ao mesmo tempo que controlavam o vale do Alto Rabagão.

A barragem de Pisões, obra do Estado Novo, desenvolve um espelho de água (Figura 5) onde se reflete a cor do céu permitindo na atualidade o desenvolvimento de alguns desportos náuticos. A sua construção deixou algumas aldeias na borda da água tendo sido destruídos os lameiros que serviam de base á sua economia, baseada na criação de gado bovino, facto, pelo qual, ainda hoje os barrosões se sentem enganados. J. Baptista (2006) ao referir-se aos grandes empreendimentos hidroelétricos desenvolvidos durante o Estado Novo ${ }^{6}$ é da opinião que os barrosões foram ludibriados na altura da construção e, ainda o continuam a ser, dado que na atualidade, não têm qualquer benefício com a produção de energia elétrica. De facto afirma:

[...] continuaremos a ser ludibriados no desvio das águas represadas? Alguns dos melhores vales estão debaixo de água. Ora, a principal fonte de subsistência dos barrosões era o gado graúdo que exige pastos permanentes: os lameiros. Os mais dos que agora temos são pasteiros abertos e sem rega ou mal regados a que também chamamos poulas. Perdemos muitos lameiros vedados e bem regados que eram destinados a produzir forragens abundantes para a longa invernia (BAPTISTA, 2006).

O vale do rio Rabagão foi escolhido pelos romanos para construírem uma das suas vias de comunicação que fazia a ligação entre Braga (Bracara angustus) e Chaves (Aqqua flavis) dois dos principais centros urbanos que promoveram no Norte do país. Propomos assim um pequeno desvio à freguesia de Vila da Ponte onde para além de podermos visitar a via romana (via XVII- do Itinerarium Antonini) pode observar-se as pontes antigas sobre o rio Rabagão ${ }^{7}$. Para além de ter sido honra, couto e sede concelhia, orgulha-se, ainda das suas villae, disseminadas ao longo do ubérrimo vale e das suas várzeas, bem testemunhadas em documentos medievais e na toponímia vigorante, bem como, dos seus castros estrategicamente colocados sobre linhas de água que entram no Regavão (BAPTISTA, 2006).
${ }^{6}$ Estado Novo é o nome do regime político autoritário e corporativista de Estado que vigorou em Portugal durante 41 anos sem interrupção, desde 1933, aquando da aprovação de sua Constituição, até 1974, quando foi derrubado pela Revolução do 25 de Abril.

Segundo Baptista (2006) o rio deveria continuara a chamar-se "Regavão. Com v ou com b, não importa visto que não tratamos de modismos. Mas era assim sempre que o povo diria! E diria bem como sempre! Ora, o mais antigo documento conbecido até boje chama-lhe Regavam (1258)!"

Geografia Ensino \& Pesquisa, v. 17, n.3, p. 191-208, set./dez. 2013.

Pedrosa, A. S. 
Figura 5 - Espelho de água da barragem de Pisões.

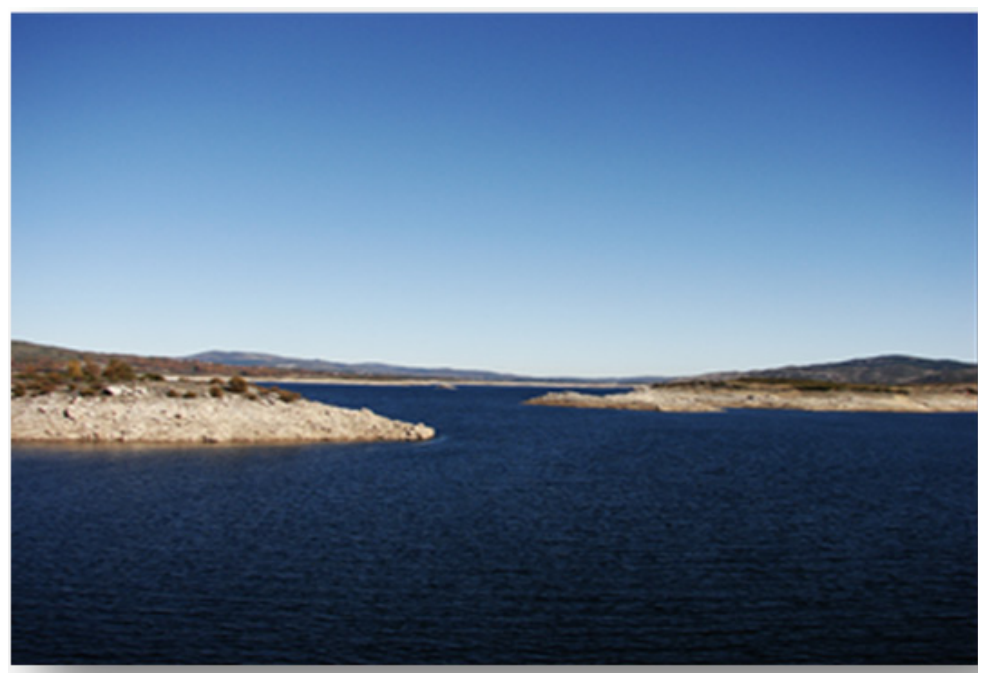

Fonte: PEDROSA, 2009.

Figura 6 - Vaso de Cista - cerca de 3.000 anos a.c.

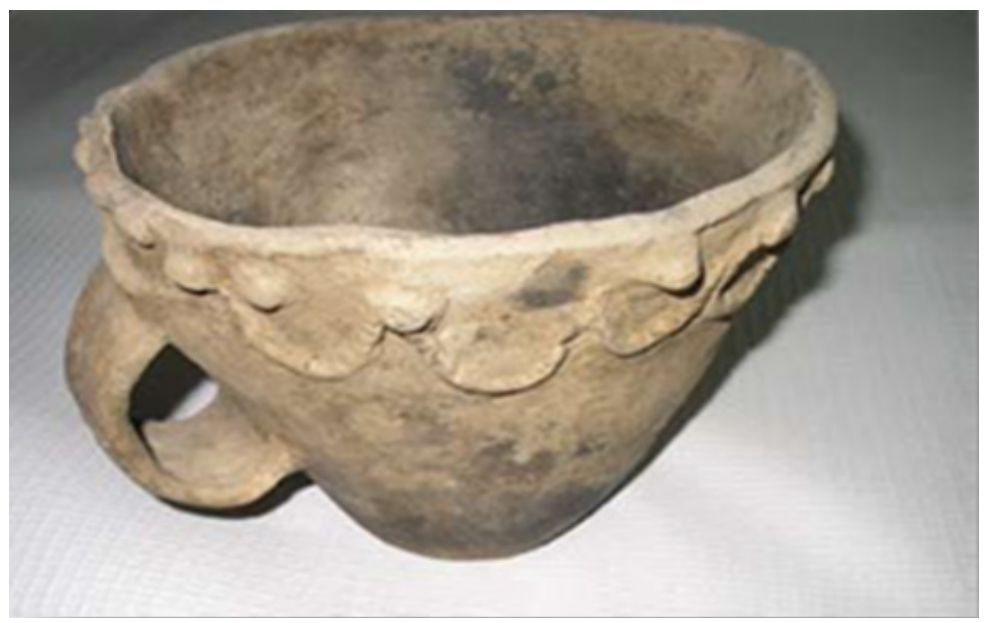

Fonte: BAPTISTA, 2006.

Pelo trilho do rio na percepção das árvores do conhecimento...

Retomamos o caminho em direção à aldeia de Covelães no Vale do rio Cávado. Enquanto fazemos o percurso notam-se algumas nuances na paisagem, relacionadas com a estrutura litológica desta área. De facto, sucede-se em alternância rochas granitóides e rochas xisto-grauvaquóides profundamente metamorfizadas, em cujas vertentes, os solos se apresentam esqueléticos e sem aptidão para a prática da agricultura. Os lameiros desenvolvem-se apenas em áreas de fundo de vale onde ocorreu a acumulação de materiais que resultaram da erosão das vertentes, nomeadamente na fase terminal da época glaciar würmiana e, posteriormente, do tardiglaciar. 
Com a aproximação ao vale principal do rio Cávado, a paisagem volta a constituir-se mais verde e a existência de solos agrícolas mais profundos, relacionados com os aluviões da planície do rio que permitiu o desenvolvimento de diversas povoações (Figura 7).

Este troço do rio Cávado possui uma das maiores e mais bem conservadas manchas autóctones de carvalhal ${ }^{8}$ de Portugal, que se localizam topograficamente acima dos campos agrícolas, onde se incluem ainda várias espécies de árvores e de arbustos, como o azevinho, o zangarinho, a lamagueira, o salgueiro e o vidoeiro, estes últimos nas áreas mais húmidas junto do rio (Figura 8).

Figura 7 - O trilho do rio e os seus principais elementos patrimoniais e paisagísticos.

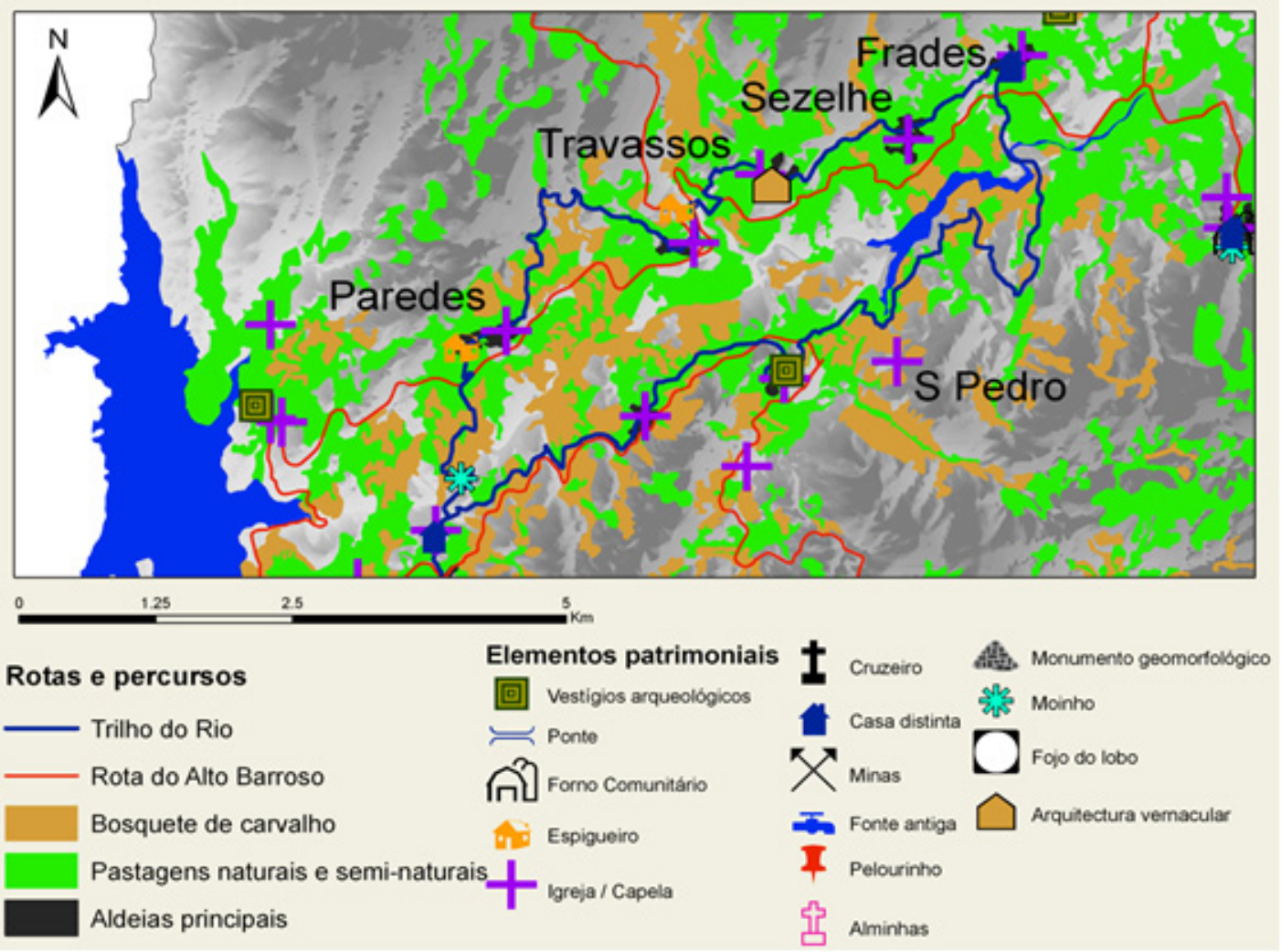

Fonte: Organizado pelo autor com base em: Cartas militares do exército 1/25000; Ecomuseu do Barroso; IGEO.

Figura 8 - As matas de carvalho no "trilho do rio".

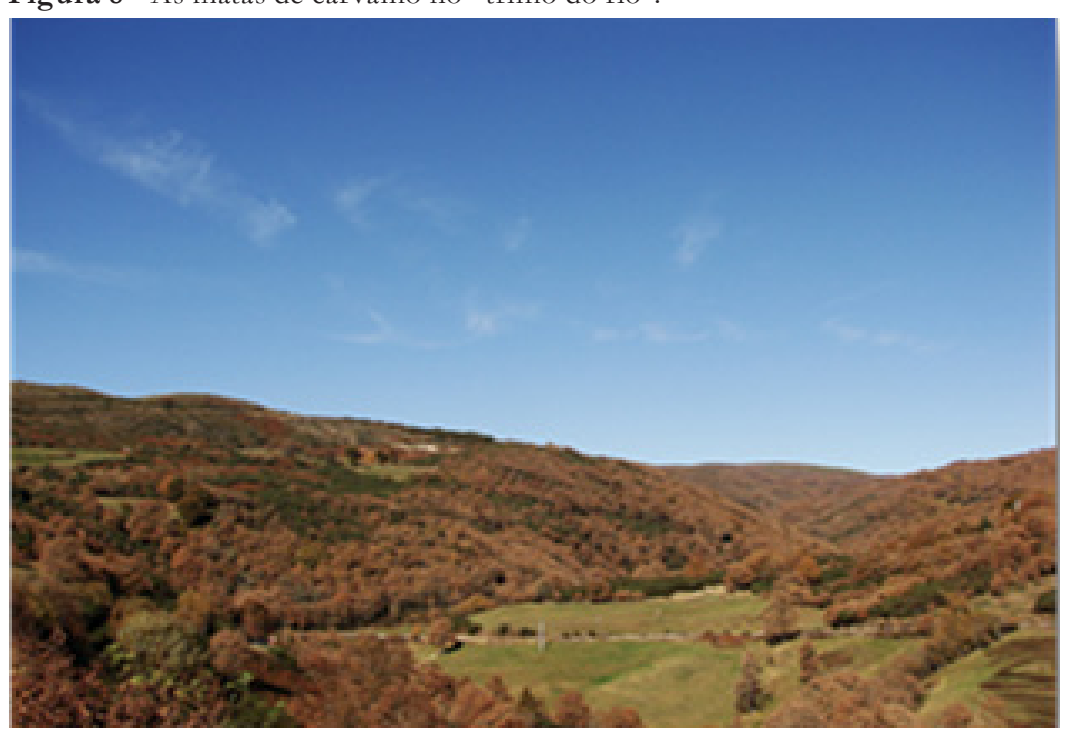

Fonte: PEDROSA, 2009.
Saliente-se a importância simbólica do carvalho entre os celtas já que era adorado como a "árvore do conbecimento", e que assume um papel central no sistema de crenças. Plínio, o Velho, no volume XVI da sua "História Natural", descreve o significado mitológico e ritual dos bosques de carvalho na cultura celta: "Groves of hard oak are chosen even for their own sake, and the magicians perform no rites without using the foliage of those trees, so that it may be supposed that it is from this custom that they get their name of Druids, from the Greek word meaning 'oak'; but further, anything growing on oak trees they think to bave been sent down from heaven, and to be a sign that the particular tree has been chosen by God himself."
Geografia Ensino \& Pesquisa, v. 17, n.3, p. 191-208, set./dez. 2013.

Pedrosa, A. S. 
${ }^{9}$ As famosas chegas de bois consistiam na luta entre dois bois do povo pertencentes a duas aldeias barrosãs. Em jogo, mais do que a fama do boi vencedor, estava a imagem de cada aldeia, representada na figura do boi. O boi do povo propriedade comum dos lavradores da aldeia que tinha como principal função a reprodução foi indiscutivelmente uma das mais características representações da vida comunitária do Barroso, "simbolo de virilidade e fecundidade - Boi é na região o alfa e o omega do quotidiano. Cada povoação revêse nele como num deus. Vitorioso cobrem-no de flores, derrotado abatem-no impiedosamente" (TORGA, 1973: 69).

${ }^{10}$ Os baldios são propriedades comunais, localizados na parte mais distante e montanhosa das aldeias que desempenham um papel muito importante para a economia aldeã. Os direitos comuns dos baldios são permanentes e ilimitados.

${ }^{11}$ Rebanho comum de gado da mesma espécie, pertencente a várias pessoas da mesma povoação. Era pastoreada nas zonas de pasto comum - baldio - ou nas terras de restolho, à vez por cada uma das pessoas de acordo com o número de cabeças de gado que tivessem, ou entre todos pagavam a um pastor para ir com a vezeira (SANTOS JÚNIOR, 1980).

Aqui desenvolve-se o trilho do rio que corresponde a um percurso de pequena rota, que faz a ligação entre diversos núcleos rurais que possuem interesses em termos de arquitetura vernacular a saber: Paredes, Covelães, Travassos, Sezelhe, Frades, São Pedro e Vilaça. Uma outra particularidade destas povoações é o aparecimento de espigueiros, destacando-se alguns com relógios de sol, sinal de que a cultura do milho neste vale substituiu o cultivo de centeio. De facto os terrenos de fundo de vale do rio Cávado são aproveitados durante os meses de verão para o cultivo do milho, que se explica pela existência de solos mais profundos e elevada disponibilidade hídrica para a sua irrigação, enquanto que de Inverno continuam a fornecer forragens para a criação de gado. Os lameiros ou prados de lima, nesta área desenvolvem-se em redor das pequenas aldeias, apresentando-se em socalcos para contrariar o declive da vertente e evitar a erosão de solos. O percurso para além de percorrer antigos caminhos murados, e pontes utilizados pelos pastores, possibilita a observação de diversos vestígios arqueológicos, património religioso e rural como os espigueiros, os moinhos de que se destaca o conjunto agrícola de Paredes com moinho, serra hidráulica e pisão, e, permite, ainda, entrar em contato com a cultura local e a vivência quotidiana nas aldeias.

Ao longo do percurso pode avaliar-se a grande diversidade de fauna, sendo este um dos poucos locais de ocorrência no nosso país de algumas espécies raras e ameaçadas. Para além de mamíferos raros como a víbora-de-seoane e a salamandralusitanica, de realçar ainda a existência no rio Cávado duas espécies de invertebrados muito raros em Portugal: escaravelho-veado e o mexilhão-de-água-doce.

Após a passagem na povoação de Travassos, onde se destaca a cabeça de um boi numa torre erigida pelo povo, monumento que evoca um campeão de chegas $^{9}$ vitorioso por diversas vezes, segue-se na direção a Pitões das Júnias e Tourém.

\section{Em busca das aldeias no planalto perdido e das vezeiras imemoriais}

A paisagem muda radicalmente já que grande parte do percurso se faz pelas pastagens naturais permanentes associados aos baldios ${ }^{10}$ (Figura 9) terrenos comunitários, onde, ainda, hoje se pastoreiam os rebanhos de cabras e ovelhas. Embora situando-se arredados das povoações e ocupando as partes mais altas das terras pobres da aldeia, a importância primordial dos baldios reside nas suas enormes extensões de urzes, mato e outros arbustos selvagens, fundamentais para as atividades agro-pastoris (O’NEILL, 1984). A pastorícia é uma atividade muito importante na região de Barroso, podendo observar-se as 'bezeiras', 'fatos' ou rebanhos de cabras nos montes onde, ainda, se pode observar o lobo ibérico (COSTA, 1987). As vezeiras ${ }^{11}$ são uma forma característica do modo de vida agro-pastoril, regulado pelos princípios comunitários. Neste caso, estamos perante um sistema sócio-económico baseado tanto na entreajuda durante os trabalhos sazonais, como na comunhão de bens e utilização de certos imóveis, funcionando à base dos direitos e deveres estabelecidos por uma comunidade (POLANAH, 1992; FAJARDO, 2005: BORRALHEIRO, 2005).

Pitões das Júnias,

Geografia Ensino \& Pesquisa, v. 17, n.3, p. 191-208, set./dez. 2013

A rota cultural na senda da paisagem, da cultura, do património, das tradições....
[...] herdeira natural da velhíssima freguesia de São Vicente do Gerês, nas profundezas do rio Beredo, que recebe águas de vários ribeirinhos na montanha, Pitões é a povoação mais alta de Barroso, na cota dos 1100 metros. Este facto contribuiu em grande medida para a elevada qualidade do presunto e fumeiro desta localidade (BAPTISTA, 2006). 
É aqui que se situa o limite natural da região do Barroso que se faz por uma falha tectónica, aproveitada pela ribeira das Aveleiras, que define de uma forma muita clara, dois tipos de paisagens: a do Barroso muito mais humanizada e a do Gerês extremamente agreste com um predomínio absoluto da rocha a nú resultante não só da litologia, mas da existência de muitos vales de fratura onde predominam os declives fortes sinais de uma tectónica ativa e intensa (Figura 10).

Figura 9 - As pastagens pobres do planalto de Pitões.

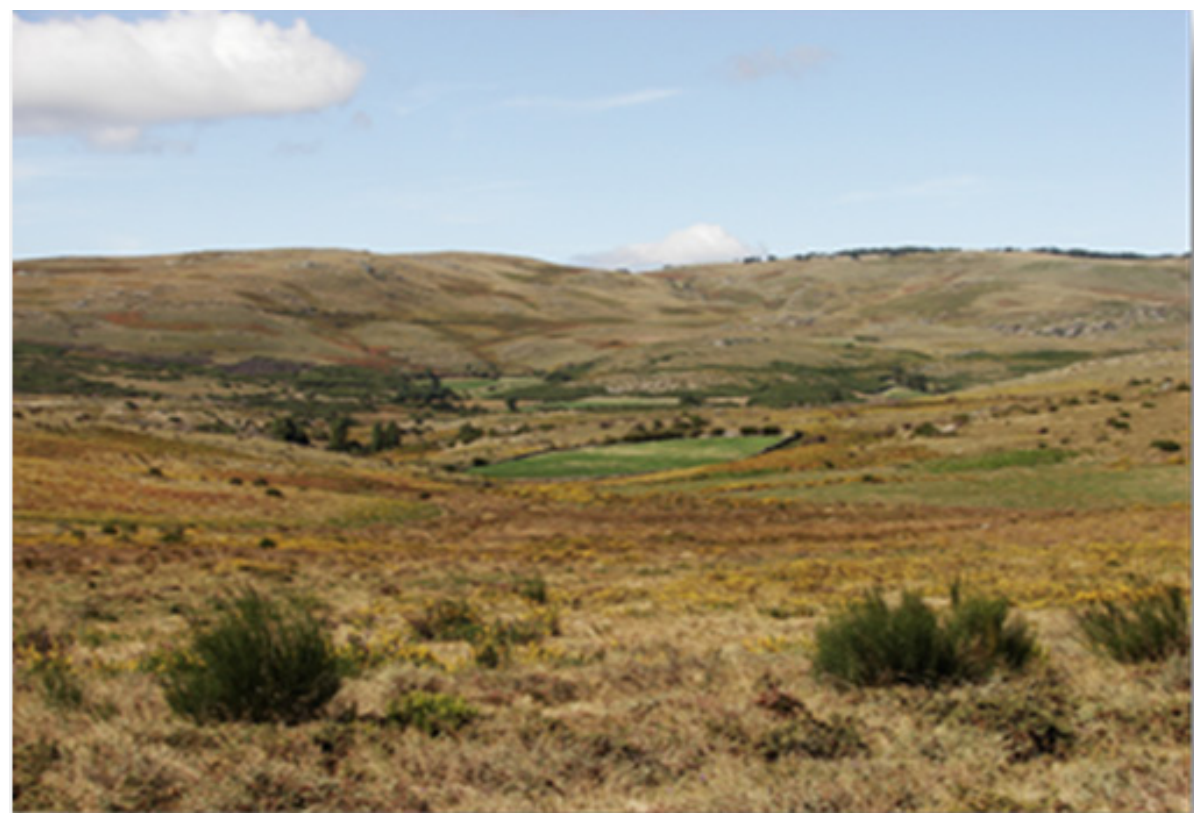

Fonte: PEDROSA, 2009.

Figura 10 - A aldeia de Pitões das Júnias: note-se o contraste geomorfológico entre a região do Barroso e a do Gerês.

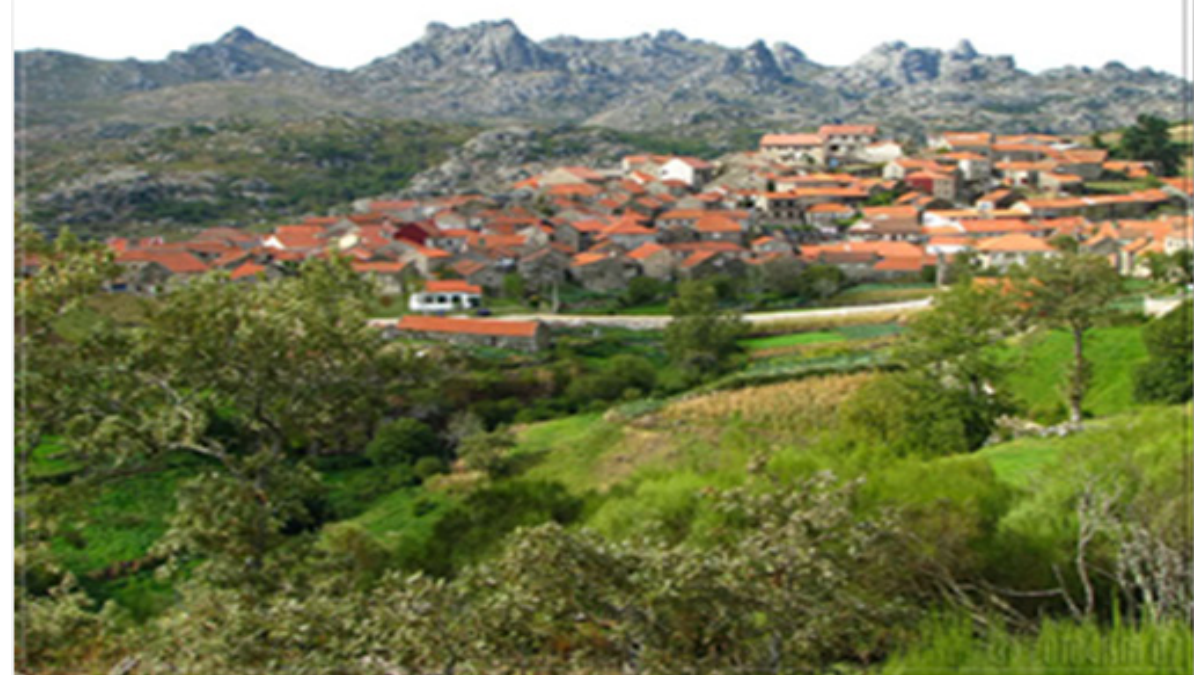

Fonte: BAPTISTA, 2006.

Num pequeno trilho que se inicia em Pitões da Júnias é possível observar o Mosteiro de Santa Maria das Unhas ${ }^{12}$, construído durante o século XII, uma das raríssimas jóias da arqueologia religiosa românica de Barroso, e que urge recuperar dado o seu legado histórico-patrimonial (Figura 11). Mas os geomonumentos também estão presentes seja através de quedas de água da qual se destaca a cascata do ribeiro do Campesino, diversos rápidos neste rio e, ainda, na ribeira das Aveleiras e rio Beredo, formas de pormenor associados á erosão dos rios (marmitas de gigante, rochas polidas, pequenas represas naturais) ou, mesmo, algumas formas geomórficas e microformas graníticas.
12 Está classificado como Monumento Nacional pelo Dec 37728 de 5 de Janeiro 1950. Este convento teve origem num antigo eremitério de origem pré-românica que foi fundado no Século IX e cuja implantação obedeceu a critérios de isolamento, o que explica o seu grandioso fundo paisagístico.

Geografia Ensino \& Pesquisa, v. 17, n.3, p. 191-208, set./dez. 2013.

Pedrosa, A. S. 
Terra ocupada à muitos milhares de anos como testemunham as imensas mamoas que se encontram no planalto, também o foi pelos celtas como atestam os vestígios do castro, próximo da Fraga de S. João, e pelos romanos que deixaram cultura e religião, para além de terem explorado o ouro no Ouroso, ferro no Ferrenho, esmeraldas e berilo, nas envolvências da aldeia (COSTA, 2006).

A povoação de Pitões das Júnias situada a 1100 metros de altitude é a mais alta do planalto barrosão, apresenta, uma estrutura típica das aldeias barrosãs com alguns bons exemplos de arquitetura vernacular. Destacamos ainda a igreja barroca de S. Rosendo, santo sepultado em Celanova (Espanha) no Séc. X.

Figura 11 - O trilho de Pitões das Junias e do contrabando de Tourém e o seu enquadramento geo-paisagistico.

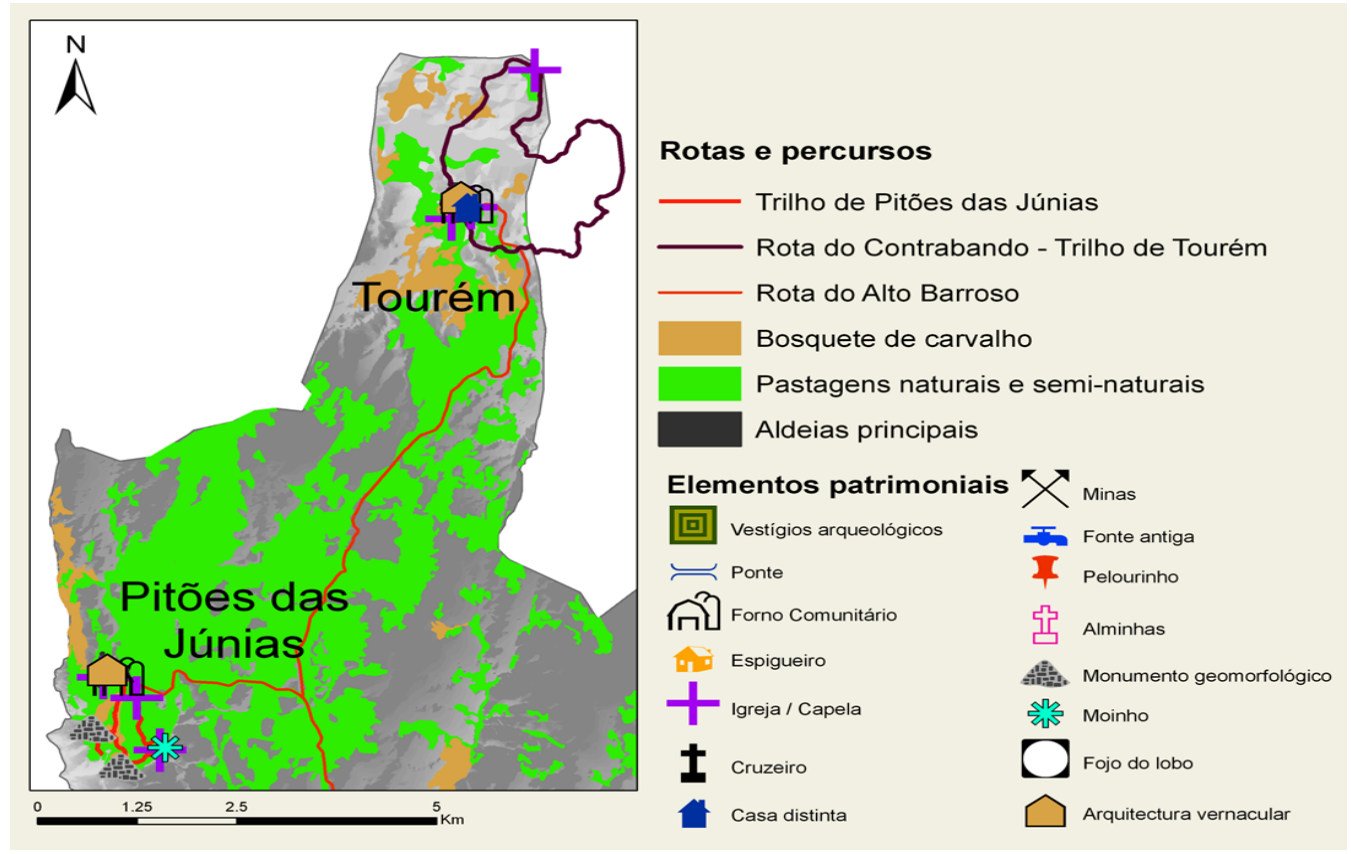

Fonte: Organizado pelo autor com base em: Cartas militares do exército 1/25000; Ecomuseu do Barroso; IGEO.

13 O tratado de Lisboa de 1864 foi um tratado firmado entre as duas monarquias da Península Ibérica em 29 de Setembro de 1864, pelo qual se fixaram definitivamente, as fronteiras ainda hoje vigentes entre Portugal e Espanha, desde a foz do Rio Minho até à confluência da Ribeira do Caia com o Rio Guadiana.

Geografia Ensino \& Pesquisa, v. 17, n.3, p. 191-208, set./dez. 2013

A rota cultural na senda da paisagem, da cultura, do património, das tradições....

\section{Por fronteiras de contrabandos...}

A caminho de Tourém recuperamos a paisagem de planalto e das pastagens pobres até iniciarmos a descida por entre carvalhais, para a aldeia de Tourém localizada no limite da planície aluvial do rio Salas (Figura 12).

A aldeia de Tourém, apresenta um harmónico conjunto de casas - na sua maioria do século XVIII (Figura 13) - que revelam ao visitante um invejável património construído donde podemos salientar a Casa dos Braganças, a capela de S. Lourenço do século XVI, a igreja matriz com vestígios românicos, o forno do povo, entre outros.

Foi uma das aldeias integrantes do Couto misto, juntamente com as povoações de Santiago, Rubiás e Meaus, agora aldeias espanholas, que durou até 1868, data de entrada em vigor do Tratado de Lisboa de $1864^{13}$.

Esta figura administrativa medieval apresentava organização própria e, não estava ligada nem à Coroa portuguesa nem à espanhola. Entre os direitos e privilégios deste pequeno território encontravam-se nomeadamente: i) a existência de um e asilo para os foragidos da justiça portuguesa ou espanhola; ii) de não fornecer soldados nem para um reino nem para o outro; iii) isenção de impostos, de liberdade de comércio e a liberdade de cultivos como, por exemplo, o do tabaco, entre outros. Os habitantes do Couto Misto não eram obrigados a optar por nenhuma naturalidade, não estavam obrigados a utilizar 
documentos de identidade pessoais, não estando sujeitos aos efeitos jurídicos de qualquer das nacionalidades: eram considerados como "mistos". Para, além disso, não eram obrigados a pagar tributos a Portugal ou à Espanha, quer os devidos pela terra ou pela prática de atividades comerciais ou industriais, quer pelos de consumo, sucessão ou outros. Os habitantes do Couto dispunham de um caminho neutro, de cerca de $6 \mathrm{~km}$ de extensão, que, partindo do Couto, atravessava as terras de Calvos de Randín, na Galiza, e chegava a Tourém, em Portugal, seu destino. Era delimitado por mourões ou marcos de pedra, marcado com diversos sinais, nomeadamente com cruzes. Utilizado para o trânsito de pessoas e de mercadorias, as autoridades de ambos os países não podiam realizar nenhuma apreensão dentro de seus limites, nem de molestar os seus usuários.

Figura 12 - A aldeia de Tourém no limite da planície aluvial do rio Salas.

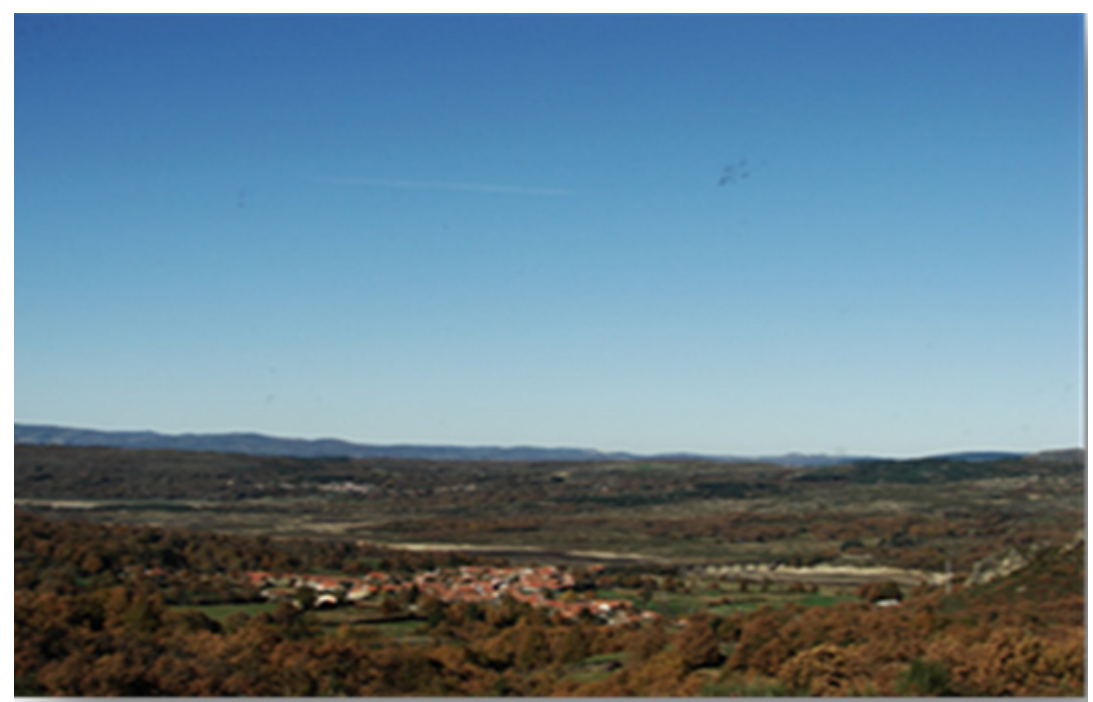

Fonte: PEDROSA, 2009.

Figura 13 - Pormenor das casas na povoação de Tourém.

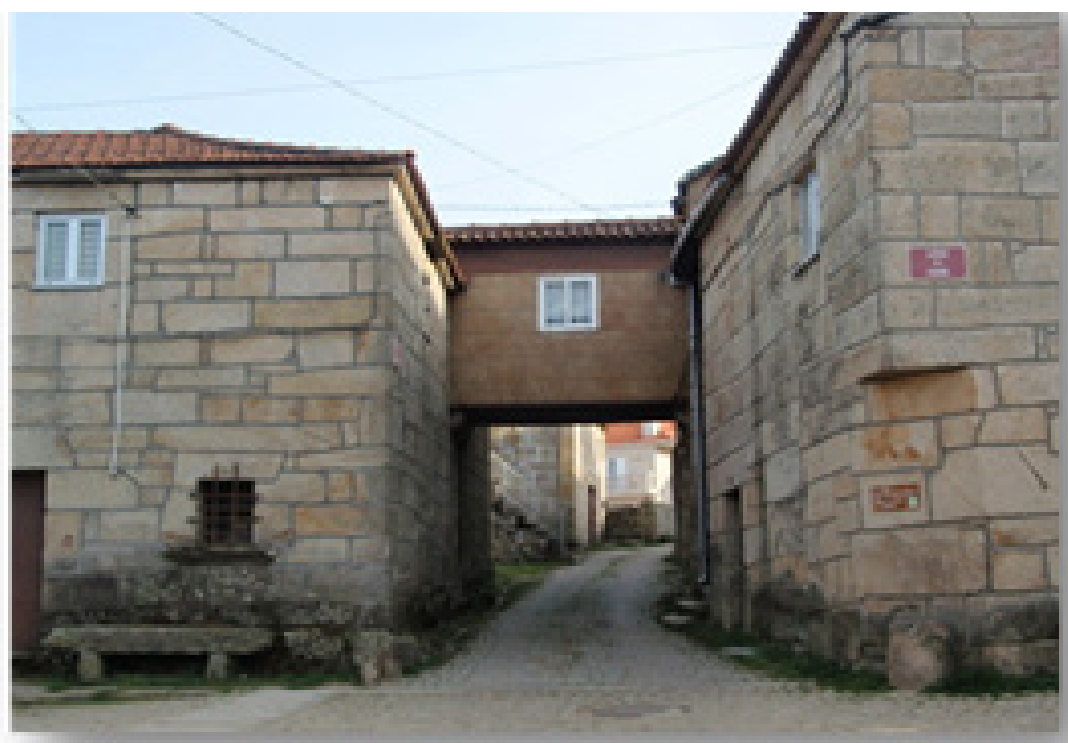

Fonte: BAPTISTA, 2006.

Junto de Tourém foi desenvolvido um pequeno trilho - a rota do contrabando - que interliga as aldeias de Tourém e Randín e recupera uma das antigas rotas do contrabando ${ }^{14}$ (Figura 11). Permite atravessar caminhos murados, campos de cultivo e carvalhais centenários, bem como entrar em contato com a cultura destes povos
14 Por estes trilhos passou um pouco de tudo: bacalhau, azeite, tecidos e mesmo bananas, bens essenciais que em tempos de miséria era possível encontrar mais baratos em Espanha. Para o lado de lá ía, sobretudo tabaco e café. Um tempo de coragem e pobreza.

Geografia Ensino \& Pesquisa, v. 17, n.3, p. 191-208, set./dez. 2013.

Pedrosa, A. S. 
vizinhos e conhecer um património comum de elevada qualidade que lhes advém da altura em que faziam parte do Conto comum que, como assinalamos, prevaleceu durante séculos. O pólo do Ecomoseu do Barroso situado nesta aldeia retrata a questão do contrabando, do couto misto, dos exilados políticos e da relação transfronteiriça.

\section{No caminho das memórias vivas...}

Depois de Tourém, obrigatoriamente é necessário regressar a Travassos com o intuito de retomarmos a direção de Montalegre. Reiniciamos o percurso do Alto Cávado por entre a presença dos lameiros tendo sempre como pano de fundo os Carvalhais na meia vertente e a vegetação arbustiva e subarbustiva na parte superior das mesmas. É claro o escalonamento da ocupação do solo, em função da altitude.

A aldeia de Cambeses do Rio é paragem obrigatória não apenas por situar lá, a "casa celta", e se apresentar com um "altissimo nivel de rusticidade e tipicismo"(BAPTISTA, 2006), mas porque é uma das aldeias onde a cultura do centeio ainda é parte importante da sua economia. Situa-se numa área de xistos a uma altitude de 1000 metros, exposta aos ventos frios e cortantes do setentrião, cujos solos se apresentam como dos mais pobres do Planalto Barrosão. Assim, a cultura de centeio é aquela que se adapta melhor a estes solos, já que nas áreas xistentas apenas existe água disponível para a prática de uma agricultura de irrigação nos fundos de vale. Os agricultores desta povoação continuam a praticar esta cultura de sequeiro, facto que tem contribuído para que as segadas e malhadas ainda se mantenham e sejam testemunhos de mais um dos trabalhos comunitários do povo barrosão (TABORDA, 1932; TEIXEIRA, 2005). São tarefas que ocorrem nos meses de verão e relacionam-se com a ceifa do cereal (segadas) e, inerentes a elas, o retirar do grão (malhadas), que se fazia nas eiras, trabalhos que exigiam uma elevada mão de obra, daí a entreajuda dos vizinhos ${ }^{15}$ (Figura 14).

Nesta aldeia passa também um trilho (o trilho do Ourigo) que permite observar in loco a apresentação os principais aspectos que assinalamos e, ainda os diferentes tipos de rocha, características desta área onde se salienta a alternância entre xistos e granitos, para além de diversos aspectos de fauna e flora.

${ }^{15}$ Era necessário ainda fazer a meda. Esta também era feita segundo um rito ancestral que consistia em fazer uma "espécie de cruz com os quatro primeiros molhos.(...) ao terminar a meda, em cada uma, faz-se no corucho da meda uma cruz de palba, para proteger o pão."

Geografia Ensino \& Pesquisa, v. 17, n.3, p. 191-208, set./dez. 2013

A rota cultural na senda da paisagem, da cultura, do património, das tradições....

Figura 14 - Os trabalhos tradicionais relacionados com o centeio em Cambeses.

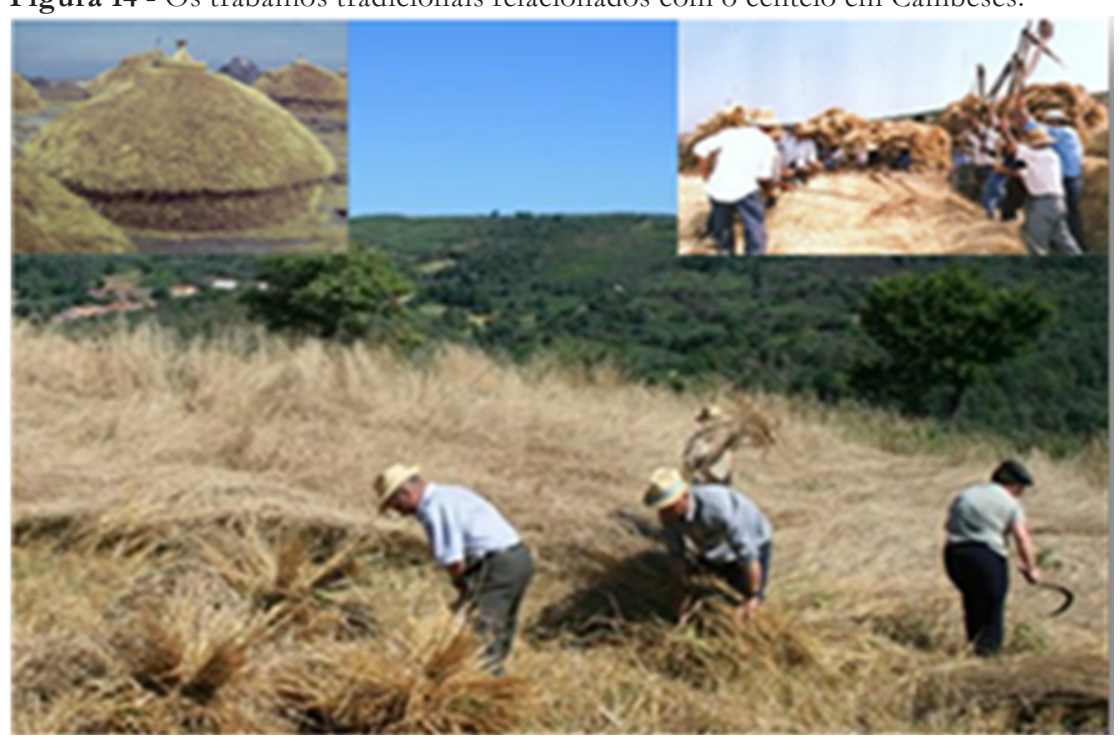

Fonte: BAPTISTA, 2006. 
antigo castro, dominando todo o vale do Alto Cávado, que durante séculos foi o garante da fronteira portuguesa nestas regiões esquecidas do poder central. O centro histórico da vila apresenta-se bem conservado e apresenta alguns edifícios de arquitetura civil e religiosos dignos de visita. O castelo de Montalegre tem servido de pano de fundo para as cada vez mais populares sextas feiras 13 - dia de Bruxas (Figura 15). Segundo J. Baptista (2006) "em Montalegre são cada vez mais os "crentes" e juntam-se em lauto jantar, com vestimenta adequada cada sexta-feira-13. Não faltam as lustrações e libaçoès (mas sem água) antes com maduros on verdes e "queimadas" sacrificiais do alho, do sal virgem e da maçã na aguardente acompanhada liturgicamente com ensalmo a condizere". É a recuperação, teatralizada, de uma memória coletiva onde as superstições, a prática de arquétipos gentílicos, de atos ritualísticos sempre estiveram presentes desde tempo imemoriais e que nunca foram esquecidos (MORAIS, 1925; FONTES, 1982; FONTES, FONTE, 2005; GONÇALVES, 2008, PEDROSA, 2012).

Finalmente mais uma curiosidade desta localidade portuguesa, já que é a única a possuir um chegódromo local onde, atualmente, se realizam as populares chegas de bois de raça barrosã.

Figura 15 - Castelo de Montalegre: sextas feiras 13 - dia de Bruxas.

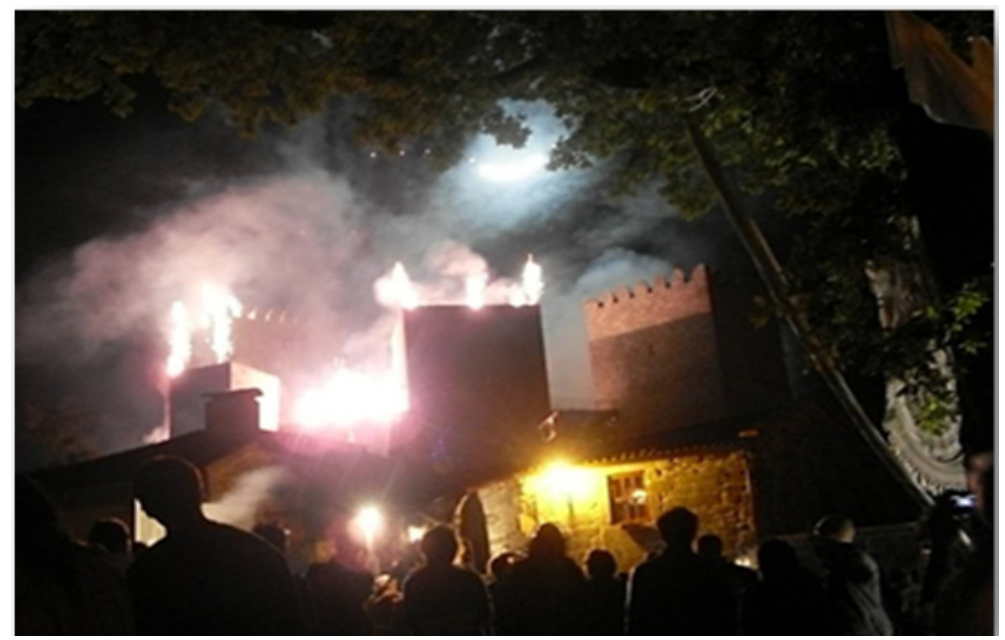

Fonte: PEDROSA, 2010.

Depois de sair de Montalegre em direção a Chaves é obrigatória a passagem por Solveira, freguesia onde os vestígios arqueológicos de diversas fases da história são importantes, nomeadamente pela presença de diversos castros, na qual se inclui a própria povoação atual (SILVA, 2010). Foi uma das seis honras ${ }^{16}$ do Barroso, que estavam obrigadas a enviar homens para a guarda do Castelo da Piconha, um dos seis ${ }^{17}$ castelos medievais que existiam na região do Barroso. Independentemente de tudo, a povoação de Solveira é extremamente antiga, havendo referências anteriores à nacionalidade e que a própria estrutura organizacional do povoado atual, ainda o demonstra, sendo em nosso entender um castro que se manteve sempre vivo ao longo da história da região do Barroso (Figura 16).
${ }^{16}$ Honra - é uma manifestação clássica do senhorialismo medieval. Era uma forma de propriedade senhorial típica de nobres laicos, que conferiam a determinado território e povoação alguns direitos de imunidade. O grau de imunidade destes territórios nem sempre era $\mathrm{O}$ mesmo, no entanto, consistia fundamentalmente em três aspectos: isenção de encargos fiscais face à Coroa; direito de administrar a justiça; direito de impedir a entrada de oficiais régios no seu território. Foram figuras administrativas que se mantiveram até ao século XIX, altura em que se processa a reforma administrativa liberal, levando a um novo mapa de Portugal (CARDOSO, 1998).

17 Eram os seguintes os castelos medivais localizados na raia barrosã: Castelo de Montalegre, Castelo da Piconha, Torre de Seirrãos, Castelo do Portelo, Castelo de O Gerês e Castelo de São Romão (BAPTISTA, 2006) 
Figura 16 - Povoação de Solveira

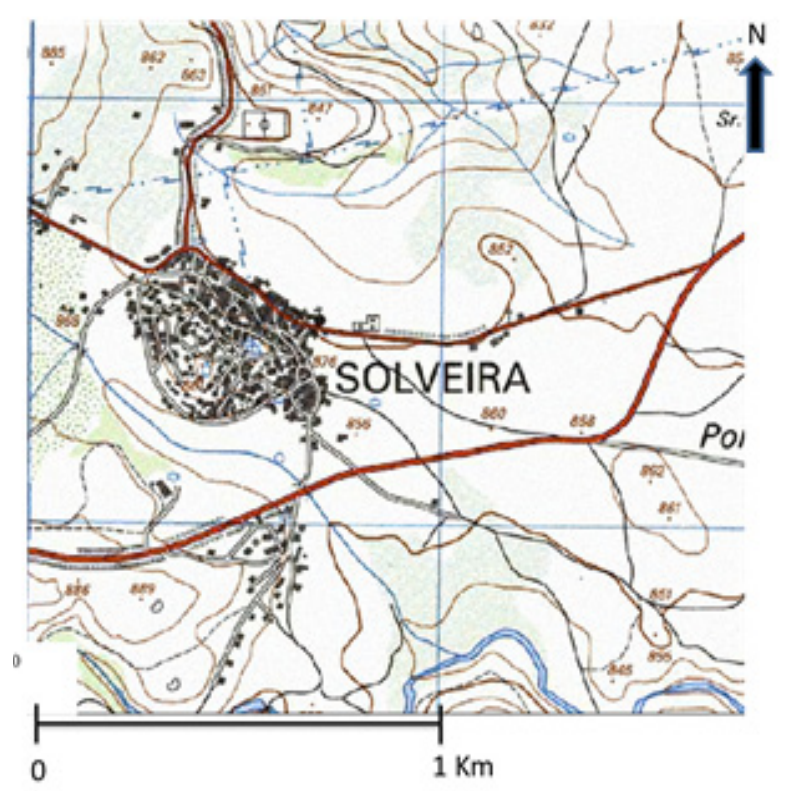

Fonte: Carta Militar, no 20 (1/25000)

\section{O caminho do Jacobeu: entre o profano e o sagrado}

A povoação de Vilar de Perdizes, outra das honras do barroso é bem conhecida a nível nacional pelo facto de se realizar há quase três décadas o Congresso de Medicina Popular cuja organização se deve a um padre.

Desde a sua origem que ocorrem ao evento gente de todas as condições, ávidas de cultura e tradições. Estão presentes médicos, cirurgiões, especialistas de nomeada e, obviamente, também apareciam os "vendedores de banha de cobra". Funciona como ponto de encontro de culturas, credos, medicinas, religiões, saberes, uma feira original popular e erudita, um espaço para questionar métodos e crenças, novidades e antiguidades e uma ocasião para conhecer o país real, profundo, oculto, esquecido, marginalizado. Vendem-se licores de todo o género, chás, infusões e, mais recentemente até os "bruxos" estão presentes. Passam três dias em Vilar

${ }^{18}$ As chamadas carrilheiras do Barroso.

${ }^{19} \mathrm{O}$ seu ponto mais elevado atinge os 1527 metros de altitude.

Geografia Ensino \& Pesquisa, v. 17, n.3, p. 191-208, set./dez. 2013

A rota cultural na senda da paisagem, da cultura, do património, das tradições.... de Perdizes, atarefadas à procura do mito! (BAPTISTA, 2006). O sagrado e profano, mais uma vez lado a lado na região do Barroso.

É também por aqui que se desenvolve a rota do Jacobeu. Mais uma vez o sagrado e o profano confundem-se no Barroso (FONTES, 1992). Este trilho ou pequena rota utiliza caminhos de terra batida ${ }^{18}$ que faziam a ligação das povoações e, ainda, antigos caminhos que percorrem a serra do Larouco muitos deles murados o que permite uma certa romantização do percurso. Percorre vários núcleos rurais que se encontravam ao longo do caminho de Santiago e desenvolvese por duas zonas com características paisagísticas e biológicas completamente distintas. Essa diferença é marcada pela Serra do Larouco, segunda mais alta montanha de Portugal continental ${ }^{19}$ e conhecida localmente como mastodôntico, nevoento e ventoso, o que diz bem da sua influência no comportamento de determinados elementos climáticos. A vertente ocidental marcada pelo vale superior do Cávado, mais húmida, claramente denunciando a influência dos ventos húmidos de Oeste, predominam os lameiros de regadio e as florestas de carvalhos. A vertente da parte oriental desta serra apresenta-se mais seca e mais fria, sendo marcantes na paisagem os castanheiros e os campos de sequeiro, já que os lameiros ficam restritos aos fundos de vale dos pequenos ribeiros afluentes do rio Tâmega, tributário do rio Douro. Estes contrastes acentuados permitem uma maior a biodiversidade, sendo uma das áreas privilegiadas para a observação de aves. Por exemplo, nas turfeiras da montanha do Larouco encontramos a orvalhinha (Drosera rotundifolia), pequena planta insetívora, que raramente se encontra em Portugal. 


\section{Pelas encruzilhadas romanas perdidas no tempo...}

O segundo percurso proposto para saída da região do Barroso apresenta-se sobranceiro á serra do Leiranco e, para além, de passar por diversas povoações com um forte tipicismo barrosão é também possível, entrar em contato visual, com vários tipos de paisagem, cada uma com fauna e flora característica. Os lameiros continuam presentes, correspondendo, aqui, ao fundo de vales, destacando-se os campos de centeio bordejados por matas de carvalhos de grande porte onde subsistem várias espécies de mamíferos carnívoros, como a fuinha e o texugo além de espécies de aves, como o papa-figos e a pega.

As zonas de altitudes mais elevadas encontram-se cobertas por matos, utilizados para o pastoreio do gado caprino e ovino e onde se observam aves de rapina, como o tartaranhãocaçador e peneireiro. O rio Beça situado nesta zona de montanha apresenta densos bosques ribeirinhos de amieiro e vidoeiro, suporte de um habitat de uma fauna diversificada, como lontra, o melro-de-água e o lagarto-de-água entre outras.

Ao longo do percurso pode ainda fazer-se um trilho - Leiranco (Figura 17) -. que engloba quatro aldeias de construção tradicional, para além de outro património como as igrejas, os fornos comunitários, as fontes e lavadouros, as casas dos lavradores abastados, moinhos de água, entre outros (Figura 18).

Figura 17 - O trilho do Leiranco Tourém e o seu enquadramento geopaisagístico.



Fonte: Organizado pelo autor com base em: Cartas militares do exército 1/25000; Ecomuseu do Barroso; IGEO.

Pode visitar-se o santuário da Sra dos Galegos que inclui um conjunto arquitetónico e arqueológico com uma capela datada de 1867, um belo cruzeiro, e sepulturas antropomórficas da época medieval junto da fonte. Para além de se poderem observar diversas estruturas ligadas à secular atividade agro-pastoril, o percurso atravessa o rio Beça na secular ponte romana e sobrepõe-se à via imperial romana Prima junto da povoação de Arcos. De facto, a freguesia de Cervos:

[...] foi atravessada de lés-a-lés pela via imperial romana, a primeira ou Prima. No seu aro apareceram já três marcos miliários, o primeiro dos quais em 1813, na rua principal de Arcos, perto da Senhora do Campo, e que muito contribuiu para localizar, in situ, o verdadeiro e único trajecto da citada via. Pelos marcos viários e Moimentos ficámos também a conhecer a verdadeira localização da antiquíssima cidade pré-romana de CALADUNUM que deverá situar-se no termo desta paróquia”. (BAPTISTA, 2006).

Geografia Ensino \& Pesquisa, v. 17, n.3, p. 191-208, set./dez. 2013.

Pedrosa, A. S. 
Figura 18 - Diversos aspectos observáveis ao longo do Trilho do Leiranco.

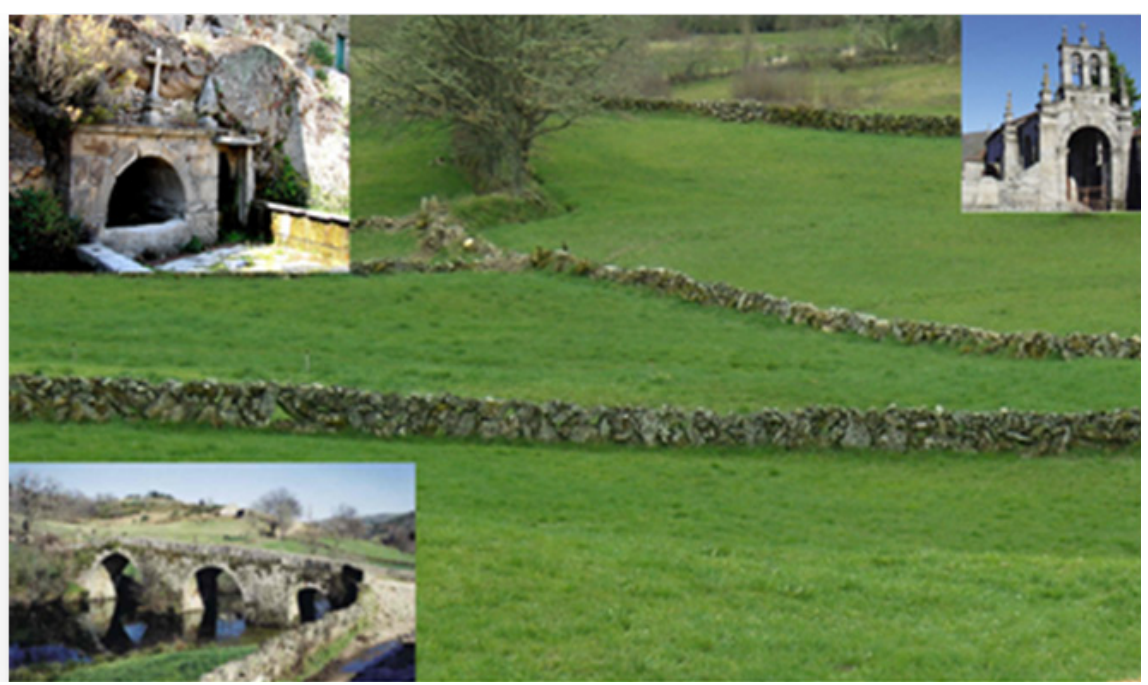

Fonte: PEDROSA, 2009.

\section{Conclusão}

Quando se pensa na concepção de uma rota ou de um circuito ele deve constituir a base das experiências que podem ser vividas pelo viajante de touring (PEDROSA, PEREIRA, 2009ª , 2009b, 2012; MARTINS \& COSTA, 2009; SANTOS et.al, 2010). A rota deve representar o eixo que estrutura, ordena e sistematiza a variedade de elementos e atividades que se reúnem num determinado espaço, facilitando ao visitante a compreensão das diversas componentes turística/culturais do território de forma que a se vá envolvendo emocionalmente com os conteúdos que são apresentados, para que se vá sentindo como fazendo parte do espaço/ território que se encontra a visitar.

\section{Referências}

ALCANTARA, L. Cintra. Trilhas interpretativas da natureza. Monografia apresentada ao Centro de Excelência em Turismo - CET, da Universidade de Brasília- UnB, Brasilia, 2007, 73p.

BAPTISTA, José Dias. Montalegre. Municipio de Montalegre, ISBN 972-8012-30-6, 2006, 156p.

BORRALHEIRO, Rogério. Montalegre - Memórias e História. Barrosana, E.M. Montalegre, 2005.

C. M. de Boticas. Preservação dos hábitos comunitários nas aldeias do Concelho de Boticas. Câmara Municipal de Boticas, (s/d), 168p.

CARDOSO, Augusto Pedro. Honras e Couto: o contributo do livro do milhão a Honra de Barbosa e o Couto do Bustelo. Cadernos Vianenses, Viana do Castelo, 23, 1998, p. 113-148.

COSTA, João Gonçalves. Montalegre e Terras de Barroso - Notas Históricas Sobre Montalegre, Freguesias do Concelho e Região de Barroso. Volume I, 2. ${ }^{a}$ Edição, Braga, Edição da Câmara Municipal de Montalegre, 1987, 235p.

COSTA, Ricardo. A cultura castreja (c. III a.C. - I d.C.): a longa tradição de resistência ibérica. Revista Outros Tempos, São Luís Universidade Estadual do Maranhão (UEMA),volume 3, (ISSN 1808-8031), 2006, p. 37-58.

Geografia Ensino \& Pesquisa, v. 17, n.3, p. 191-208, set./dez. 2013

A rota cultural na senda da paisagem, da cultura, do património, das tradições....
DRIES, Adri L.J. van den. The Art of Irrigation: The Development, Stagnation, and Redesign of FarmerManaged Irrigation Systems in Northern Portugal. PhD thesis, 2002, 353p.

FAJARDO, Sérgio. Paisagem Rural e Território económico: Algumas considerações sobre essas possibilidades de leitura do espaço agrário. Anais... III Simpósio Nacional de Geografia Agrária - II Simpósio Internacional de Geografia Agrária, Jornada Ariovaldo Umbelino de Oliveira, Presidente Prudente, 2005, 10p. http://www4.fct.unesp.br/nera/publicacoes /singa2005/Trabalhos/Artigos/ Sergio\%20Fajardo.pdf, consultado em 3 de Outubro de 2011. 
FONTES, António L. Cultura Popular da Zona do Barroso. Brigantia, Número 4, 1982, p.3-12.

FONTES, António L. Etnografia Transmontana (vol. I Crenças e tradições de Barroso; vol.2 O comunitarismo de Barroso). Lisboa, Editorial Domingos Barreira, 1992.

FONTES, António L. Cultura Popular da Zona do Barroso: Situação Geográfica - História Antiga e Moderna - Artes e Ofícios - Comunitarismo - Religiosidade Popular - Literatura Popular. Revista de Cultura- Brigantia, Volume II. N. ${ }^{\circ}$ 4. Bragança, Escola Tipográfica, 1982, p. 417- 426.

FONTES, António; FONTE, Barroso. Usos e Costumes de Barroso. 2. ${ }^{a}$ Edição.Lisboa, Âncora Editora, 206p.

GONÇALVES, Paula A. C. O Sagrado no Imaginário Barrosão e em Padre António Lourenço Fontes - Estudo Etnolinguístico, Mestrado em Ensino da Língua e da Literatura Portuguesas, Universidade de Trás-os-Montes e Alto Douro, Vila Real, 2008, 176p.

MARTINS, N.; COSTA C. Património, paisagens culturais, turismo, lazer e desenvolvimento sustentável. Exedra-Turismo e Património, no temático, 2009, p. 51-76.

MORAIS, António Gonçalves. Barroso. RLu. Vol. XXV, Lisboa, Livraria Clássica Editora, 1925, p.275 -282 .

O’NEILL, Brian Juan. Proprietários, Lavradores e Jornaleiras (Desigualdade social numa aldeia transmontana, 1870-1978), Porto, Publicações Dom Quixote, 1984, 461p.

PEDROSA, A.S. Montanha - um espaço natural historicamente construido: o exemplo das montanhas do Noroeste de Portugal. Actas ... $2^{\circ}$ Colóquio Ibero-americano de paisagem cultural, patrimônio e projeto - Desafios e perspetivas. Belo Horizonte: UFMG, 2012, v.1.

PEDROSA, A. S.; PEREIRA, A. A Geografia e as Novas Estratégias de Desenvolvimento de Territórios Periféricos. Geografia. Ensino \& Pesquisa, ed. especial - Anais do V Seminário Latino - Americano e I Ibero-Americano de Geografia Física - "aproximando experiências para a sustentabilidade de um ambiente globalizado”, Eixo 2, 12 (1), ISSN 0103 - 1538, Santa Maria, RS - Brasil, 2008, p. 151-178.

PEDROSA, A. S.; PEREIRA, A. A. Synergies between the cultural landscape and the developmente of "Alto Barroso" region: Linking multifunctional farming, traditional products and tourism offer, European Culture Expessed in Agricultural Landscape, Universidade de Cambridge, Cambridge, 2009a, 41p.

PEDROSA, A. S.; PEREIRA, A. Touring cultural e paisagístico no Alto Barroso: uma proposta integradora de patrimónios pela compreensão holística do território. Actas.. II Jornadas Internacionais de turismo: Dinâmicas de rede no Turismo Cultural e Religioso, CEDTUR, Maia, Ponte de Lima, Arcos de Valdevez, 2009b, 35p.

PEDROSA, A.S.; PEREIRA, A. A paisagem cultural como linha de concepção de uma rota turística: o exemplo do Alto Barroso - Norte de Portugal, Revista Geonorte, Edição Especial, V.2, N.4, 2012, p.46 -59 .

PEDROSA, A.S.; PEREIRA, A. A paisagem cultural como ativo de desenvolvimento de espaços rurais tradicionais de baixa densidade. RODRIGUES, C. R; MERCANTE, M. A. (ogrs). Avaliação sócioambiental do dominio dos cerrados e pantanal: métodos e técnicas, Uberlândia: UFU, Campo Grande: Anhanguera-Uniderp, Capes, 2013, p. 37-68.

PEREIRA, A.; PEDROSA, A.S. Alto Barroso region: placing cultural landscape at the core of the sense of place and at the centre of the economic strategy. Anais... 2nd Moravian Conference on Rural Research EURORURAL '10 - European Countryside under Globalization, Mendel University of Agriculture and Forestry Brno, Faculty of Agronomy, Department of Applied and Landscape Ecologyque, Brno -Czech Republic, 2010.

PEREIRA, A.; PEDROSA, A. S. Paisagem cultural das montanhas do Noroeste de Portugal: Um ciclo de construção, desestruturação e reconversão, Territorium, Revista da Associação Portuguesa de Riscos, Prevenção e Segurança, No14, 2007, p. 45-61.

PEREIRA, A.; SILVA, M.; PEREIRA, R. Serra de Arga: A marca como vector de desenvolvimento, Actas... VII CIER - Cultura, Inovação e Território, Tema II, Património: ambiente e diversidade cultural, Ed. ESAC; Coimbra, 2008, 37p. http://www.pluridoc.comSite/FrontOffice/default.aspx?module=Files / FileDescription $\& \mathrm{ID}=2795 \&$ state $=$ FD

PEREIRA, L.S.; SOUSA, V.S. Lameiros e prados de lima, uma paisagem das terras altas húmidas de Portugal. Comunicação apresentada no V Seminário Internacional CYTED-XVII. Un enfoque para la gestion sustentable del agua: Experiencias en zonas humedas, Universidad de Buenos Aires,), 2005, disponibilizado em (http://www.cyted.agua.uba.ar/V_SEM_ppt/Santos\%20Pereira/html/index.html) (consultado em 15 de Outubro de 2011).

Geografia Ensino \& Pesquisa, v. 17, n.3, p. 191-208, set./dez. 2013.

Pedrosa, A. S. 
PÉREZ, Xerardo P. Turismo Cultural. Uma visão antropológica, El Sauzal (Tenerife. España): ACA y PASOS, RTPC., 2009, 307p.

PIRES, J.M. et.al. Lameiros de Trás-os-Montes. Perspectivas de futuro para estas pastagens de montanha. Série Estudos, Escola Superior Agrária. Edição do Instituto Politécnico de Bragança. 1994, $96 \mathrm{p}$.

PLÍNIO, o Velho. História Natural, Vol. XVI: RITTER, Eva; DAUKSTA, Dainis (2006) - Ancient Values and Contemporary Interpretations of European Forest Culture - reconsidering our understanding of sustainability in forestry; Small-scale forestry conference proceedings; Proceedings of IUFRO 3.08 Conference hosted by Galway-Mayo Institute of Technology, Galway, Ireland; 79, http:/ /www.coford.ie/ media/ coford/content/publications/projectreports/smallscaleforestryconference/Ritter.pdf

POÇAS, I., CUNHA, M; PEREIRA, L. Pastagens seminaturais de montanha: Lameiros, sistemas ancestrais no século XXI, Taller CYTED XVII. El agua en Ibero-América: tecnologias apropriadas e tecnologias ancestrales. Universidade de Piura-Peru, Lima, 2006.

POLANAH, Luís. A propósito do comunitarismo na serra do Gerês. Terras de Bouro o Homem e a Serra, Ed. Câmara Municipal Terras do Bouro, 1992, p. 57-66.

SANTOS JÚNIOR, Joaquim R. A Vezeira da Cabrada do Couto de Dornelas (Barroso) e Outras Vezeiras, Porto, Sociedade Portuguesa de Antropologia e Etnologia, Faculdade de Ciências do Porto, 1980.

SANTOS, N.; GRAVIDÃO, F.; CUNHA, L. Natureza, paisagens culturais e os produtos turísticos associados ao território. Actas... $4^{\circ}$ Congresso Latino Americano de Investigação Turística., Montevideo, 2010, 26 p.

SILVA, P. Miguel Reis . Povoamento pro-Histórico do alto Tâmega: as mudanças do I milénio a,C. e a resistência do substrato indígena. Dissertação de mestrado em Arqueologia, FLUP, Porto, 2010, 88p.

TABORDA, Vergílio. Alto Trás-os-Montes - Estudo Geográfico, Coimbra, Imprensa da Universidade, 1932.

TEIXEIRA, David José Varela. O Ecomuseu de Barroso. A nova museologia ao serviço do desenvolvimento local, Dissertação apresentada para a obtenção do grau de Mestre, em Património e Turismo, Universidade do Minho, Braga, 2005, 213 p.

\section{Correspondência:}

António de Sousa Pedrosa - Universidade Federal de Uberlândia, Faculdade de Artes, Filosofia e Ciências Sociais, Instituto de Geografia. Avenida João Naves de Ávila - de 1260 a 3630 - lado par. Uberlândia, MG - Brasil, CEP - 38408100.

E-mail: aspedro@gmail.com

Recebido em 24 de junho de 2013.

Revisado pelo autor em 12 de dezembro de 2013.

Aceito para publicação em 23 de dezembro de 2013. 